\title{
シャント血流量と再循環指数の検討
}

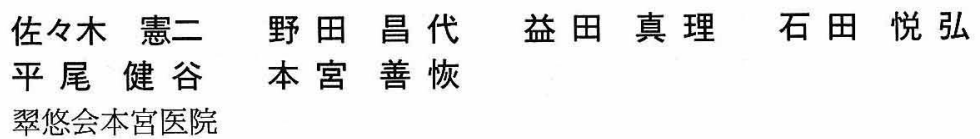

key words : shunt blood flow volume, fractional recirculation, pulse doppler

〈要旨〉

32 名の維持透析患者を対象として再循環指数（R值）を求め, パルスドップラー法により測定したシャント流量 $\left(\mathrm{Q}_{\mathrm{B}}\right)$ との比較を行った。非シャント肢およびシャント肢の血流量は各々 $28.3 \sim 235.0 \mathrm{ml} / \mathrm{min}(67.7 \pm 44.6 \mathrm{ml} / \mathrm{min})$

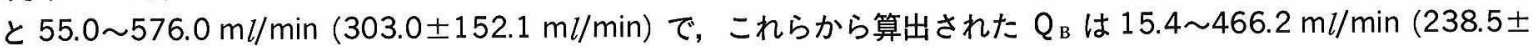
$137.8 \mathrm{ml} / \mathrm{min})$ であった. BUN 值および $\mathrm{Cr}$ 值で算出された $\mathrm{R}$ 值とシャント流量とは各々 $r=-0.658(p<0.001)$, $r=-0.548(p<0.01)$ と有意な負の相関を示した。 $R$ 值が 0.15 未満の患者群および 0.15 以上の患者群における $Q_{B}$

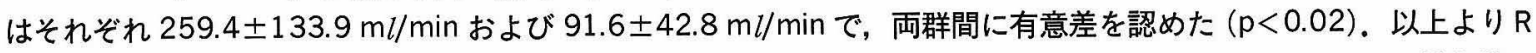
值を求める事により，シャント不全の定量的推定が可能であり，本法は種々の診断装置による推定法に比べ技術的に も簡単に行え，再現性の面においても問題なく，臨床的有用性が高いと考えられた。

\section{Study on shunt blood flow volume and fractional recirculation}

\section{Kenji Sasaki, Masayo Noda, Mari Masuda, Etsuhiro Ishida, Kenya Hirao, Yoshihiro Motomiya} Motomiya-Clinic Suiyukai

One of the most important determinants of high performance dialysis is the status of blood access ( $A-V$ shunt). In this study, we assessed the functional status of $A-V$ shunts by two methods, shunt blood flow volume $\left(Q_{B}\right)$ by the pulse doppler method and determination of fractional recirculation (R) based on the blood urea nitrogen value and serum level of creatinine. The subjects included 32 patients on maintenance hemodialysis. The blood flow rate in the brachial artery was $55.0 \sim 576.0 \mathrm{~m} / / \mathrm{min}(303.0 \pm 152.1 \mathrm{ml} / \mathrm{min})$ on the shunt side and $28.3 \sim 235.0 \mathrm{~m} / /$ $\min (67.7 \pm 44.6 \mathrm{ml} / \mathrm{min})$ on the opposite side. $Q_{B}$, which was calculated mathematically by deducting from the two measurements, was $15.4 \sim 466.2 \mathrm{ml} / \mathrm{min}(238.5 \pm 137.8 \mathrm{ml} / \mathrm{min})$. In addition, a comparative study of $Q_{B}$ was done in two patient subgroups according to $R$ values. $Q_{B}$ in the patient subgroup having an $R$ value greater than 0.15 was significantly lower than that in patients with $R$ values below 0.15 , i. e. $91.6 \pm 42.8 \mathrm{~m} / / \mathrm{min}$ vs. $259.4 \pm$ $133.9 \mathrm{ml} / \mathrm{min}$, respectively $(p<0.02)$. Moreover, a significant negative correlation between $Q_{B}$ and the $R$ value $(r=-0.658, p<0.001)$ was found. Based on those results, we conclude that the determination of $R$ value is useful for evaluating $A-V$ shunts from a practical viewpoint, which is assumed to be essential for achieving high performance dialysis.

\section{緒言}

維持透析患者の Quality of Life の最大の規定要因は 言うまでもなく至適透析である. 今日至適透析は $\mathrm{Kt} / \mathrm{V}$ 值をもって評価されることが多いが ${ }^{1,2)}, \mathrm{Kt} / \mathrm{V}$ 值が至適 domain 内の数值を満足させているにもかかわらず, 透 析不足の状態が示唆された場合, 最も留意すべき点は
シャント不全である：シャント流量は表 1 の如く諸種の 方法 ${ }^{3 \sim 7} に よ り$ 測定されているが, パルスドップラー法が 最も一般的方法となっている. しかし本法ではプローブ による圧迫の影響等技術的な不安定要素が多く, 再現性 は必ずしも満足されるものではない.この点従来より single needle dialysis においてしばしば求められていた 
fractional recirculation（R値）は極めて簡素な測定法 であり, 再現性も高いと考光られ, 最近 Windus $ら^{8)}$ 通常の透析でのシャント評価法として有用性の高いこと を報告した。我々も今回 32 名の維持透析患者を対象とし て Windus $ら^{8}$ に準じてR值を求め, パルスドップラー 法により測定したシャント流量との比較を行った。

\section{対象と方法}

\section{1. 対象}

$\mathrm{Kt} / \mathrm{V}$ 值 0.9 以上の透析条件にて維持透析継続中で, かつ橈骨動脈一橈側皮静脈吻合内シャントを blood access とする症例 32 例を対象とした。側々吻合 25 例, 側端吻合 7 例で, 全例重炭酸透析施行例であった。原疾 患の内訳は糖尿病性腎症 3 例, 慢性系球腎炎 27 例, 全身 性エリテマトーデス 1 例, 囊胞腎 1 例であった（表 2 ）。

\section{2. 再循環指数 ( $R$ 値)}

採血は Windus ら ${ }^{8)}$ の報告に準じ，透析開始後 15 分間 血流量 $200 \mathrm{~m} l / \mathrm{min}$ にて透析を行い, 動静脈ラインおよ びシャント肢以外の四肢の表在性末梢静脈より採血し (図 1)，R值を次式より算出した。なお，減少率を算出 するため透析の開始前と終了時に動脈側ラインより採血 し，尿素窒素 $(\mathrm{BUN})$, クレアチニン $(\mathrm{Cr})$ を測定した。

$$
\begin{aligned}
& \mathrm{R}=\left(\mathrm{P}_{\mathrm{BUN}}-\mathrm{A}_{\mathrm{BUN}}\right) /\left(\mathrm{P}_{\mathrm{BUN}}-\mathrm{V}_{\mathrm{BUN}}\right) \\
& \text { より採血した BUN 濃度 }
\end{aligned}
$$
1）電磁血流計による評価法
2) 色素希彩法4)
3) 一時閉塞法 ${ }^{5,6)}$
4) パルスドップラー法”$$
\mathrm{P}_{\mathrm{BUN}} \text { ：シャント肢以外の四肢の表在性末梢静脈 }
$$

$\mathrm{A}_{\mathrm{BUN}}$ ：ダイアライザーの血液流入部での BUN

$\mathrm{V}_{\mathrm{BUN}}$ ：ダイアライザーの血液流出部での BUN
3 . パルスドップラー法による血流量の測定法 ALOKA SSD-630にて $7.5 \mathrm{MHz}$ のプローブを用い, 非シャント側, シャント側肘関節部上腕動脈での流速を 測定し，同部の面積を乗じて算出した(図 2 )。それぞれ の典型的な映像を示した. 図 2 a は非シャント肢での映 像であるが，規則正しい継続的な振幅度の低い拍動波が みられる. 図 $2 \mathrm{~b}$ は血流 $100 \mathrm{~m} l / \mathrm{min}$ の低流量のシャン 卜肢での映像であり, 比較的振幅度の低い連続的波形が

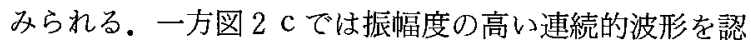
め,いわ氻る繰り返し現象の明らかな映像となっている. 図 $2 \mathrm{c}$ の平均血流量は $576 \mathrm{ml} / \mathrm{min}$ であった。

\section{結果}

\section{1. $\mathrm{R}$ 值}

BUN 值から求めた $\mathrm{R}$ 值は $0.01 \sim 0.23(0.073 \pm 0.054)$ で, 32 例中 0.05 以下は 14 例 $(43.8 \%), 0.1$ 以下 24 例 $(75 \%) ， 0.15$ 以上は 4 例 (12.5\%) であった。一方 $\mathrm{Cr}$ 值 から求めた R 值は $0 \sim 0.22(0.059 \pm 0.053) て ゙, 0.05$ 以 下は 17 例 $(53.1 \%), 0.1$ 以下 25 例 $(78.2 \%), 0.15$ 以 上 1 例（3.2\%）であり， BUN から求めた R 值とは $\mathrm{r}=$ $0.847, \mathrm{p}<0.001$ の高い正の相関を示した.
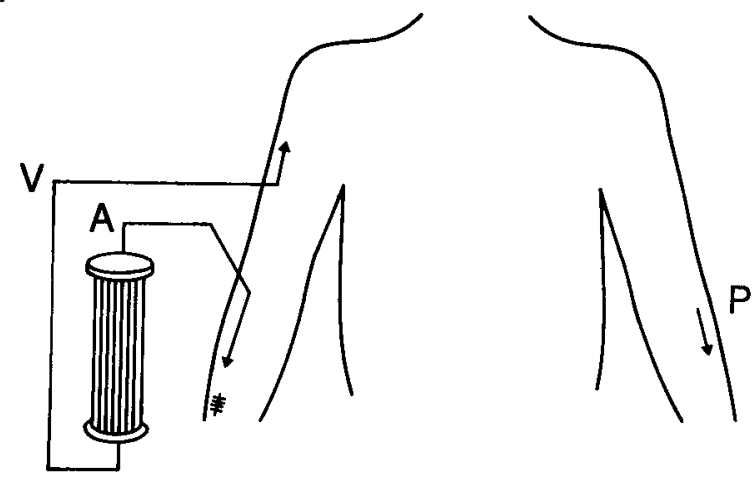

\begin{tabular}{|c|c|c|c|c|c|c|c|}
\hline & $\begin{array}{c}\text { Case } \\
\text { (number) }\end{array}$ & $\begin{array}{c}\text { Age } \\
\text { (years) }\end{array}$ & $\begin{array}{l}\text { Shunt flow } \\
(\mathrm{m} l / \mathrm{min})\end{array}$ & $\begin{array}{c}\text { BUN } \\
(\mathrm{mg} / \mathrm{d} l)\end{array}$ & $\begin{array}{c}\mathrm{Cr} \\
(\mathrm{mg} / \mathrm{d} l)\end{array}$ & $\begin{array}{c}\mathrm{UA} \\
(\mathrm{mg} / \mathrm{d} l)\end{array}$ & $\begin{array}{c}\mathrm{P} \\
(\mathrm{mg} / \mathrm{d} l)\end{array}$ \\
\hline Male & 13 & $\begin{array}{c}52.2 \\
\pm \\
10.7\end{array}$ & $\begin{array}{c}267.5 \\
\pm \\
156.9\end{array}$ & $\begin{array}{c}95.7 \\
\pm \\
15.5\end{array}$ & $\begin{array}{c}13.1 \\
\pm \\
2.2\end{array}$ & $\begin{array}{c}6.8 \\
\pm \\
1.3\end{array}$ & $\begin{array}{c}6.7 \\
\pm \\
2.0\end{array}$ \\
\hline Female & 19 & $\begin{array}{c}54.9 \\
\pm \\
13.2\end{array}$ & $\begin{array}{c}218.6 \\
\pm \\
123.5\end{array}$ & $\begin{array}{c}86.6 \\
\pm \\
21.7\end{array}$ & $\begin{array}{c}9.9 \\
\pm \\
2.7\end{array}$ & $\begin{array}{c}7.6 \\
\pm \\
1.5\end{array}$ & $\begin{array}{c}6.5 \\
\pm \\
1.4\end{array}$ \\
\hline Total & 32 & $\begin{array}{c}53.8 \\
\pm \\
12.1\end{array}$ & $\begin{array}{c}238.5 \\
\pm \\
137.8\end{array}$ & $\begin{array}{c}90.3 \\
\pm \\
19.7\end{array}$ & $\begin{array}{c}11.2 \\
\pm \\
2.9\end{array}$ & $\begin{array}{c}7.3 \\
\pm \\
1.4\end{array}$ & $\begin{array}{c}6.6 \\
\pm \\
1.7\end{array}$ \\
\hline
\end{tabular}

図 1 Fractional recirculation (R). $\mathrm{A}:$ arterial line, $\mathrm{B}$ : venous line, $\mathrm{P}$ : peripheral vein.

表 2 Profile of cases involved

Primary disease : CGN 27, DM 3, others 2 


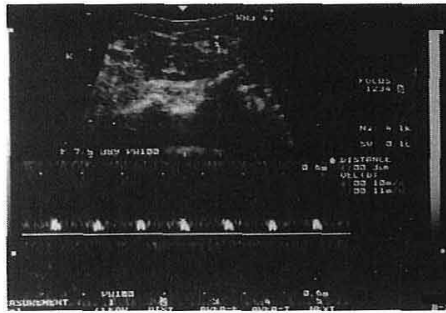

a

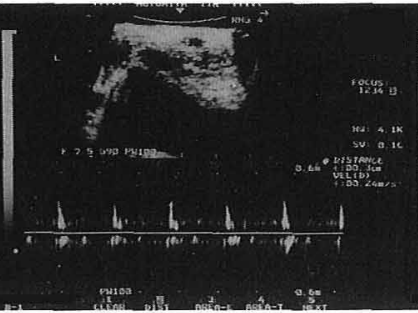

b

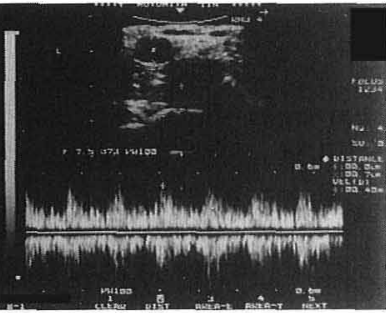

c

図 2 Pulse doppler method

a : brachial artery on the opposite side to the shunt. b, c : brachial artery on the shunt side at blood flow rate of $100 \mathrm{ml} / \mathrm{min}$. and $576 \mathrm{ml} / \mathrm{min}$. respectively.

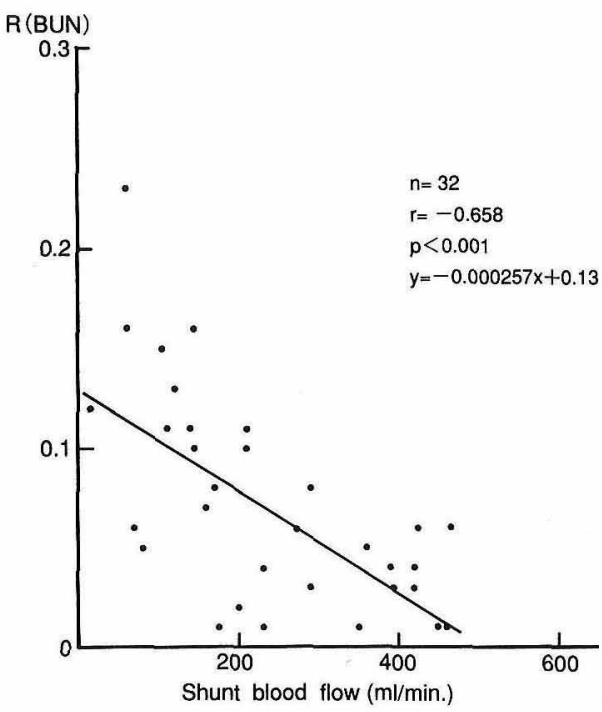

図 3 Shunt blood flow vs. fractional recirculation calculated by BUN concentration.

2.シャント血流量

シャント肢で得られた血流量から対側肢の血流量を差 し引き算術的にシャント血流量を求めた結果，15.4〜 $466.2 \mathrm{ml} / \mathrm{min}(238.5 \pm 137.8 \mathrm{~m} l / \mathrm{min})$ のシャント流量が 確認された。また対側肢での血流量は28.3〜235.0 ml/ $\min (67.7 \pm 44.6 \mathrm{ml} / \mathrm{min})$ であった。対側肢の約 5 倍 $(338.5 \mathrm{ml} / \mathrm{min})$ 以下のシャント肢血流量例は 32 例中 20 例 $(62.5 \%$ )，刘側肢の 5 10 倍 (338.5 677.0 ml/min) に相当する血流量例は 12 例（37.5\%）であった。

3.シャント血流量と $\mathrm{R}$ 值

シャント血流量は BUN 值で算出された $\mathrm{R}$ 值と $\mathrm{r}=$ $-0.658(\mathrm{p}<0.001), \operatorname{Cr}$ 值で求められた R 值と $\mathrm{r}=$ $-0.548(\mathrm{p}<0.01)$ といずれも有意な負の相関を示した (図 $3 ， 4$ )。また $\mathrm{R}$ 值 0.15 末満の症例群 $(n=28)$ での シャント血流量 $15.4 \sim 466.2 \mathrm{ml} / \mathrm{min} \quad(259.4 \pm 133.9 \mathrm{ml} /$

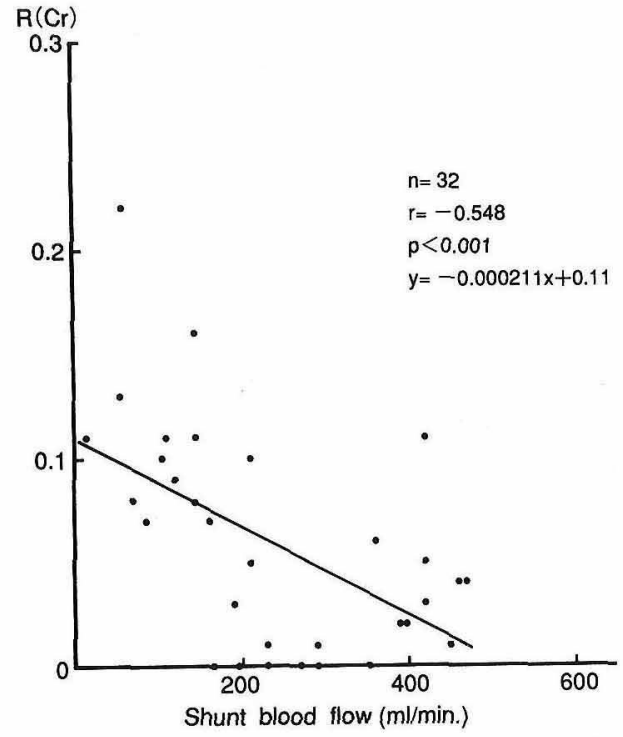

図 4 Shunt blood flow vs. fractional recirculation calculated by $\mathrm{Cr}$ concentration. $\mathrm{Cr}$; creatinine.

$\min )$ に対し， R 值 0.15 以上の症例群 $(n=4)$ でのシャ ント血流量は $55.0 \sim 146.0 \mathrm{ml} / \mathrm{min}(91.6 \pm 42.8 \mathrm{ml} / \mathrm{min})$ と明らかに低值 $(\mathrm{p}<0.02)$ であった。

4. 溶質 (BUN, Cr) 減少率と R 值

各溶質の減少率を回路動脈側採血による通常の方法で 求め，R值と比較した結果，BUN 減少率と BUN で求 めた R值とは $\mathrm{r}=0.151$ (n. s.), $\mathrm{Cr}$ 減少率と $\mathrm{Cr}$ で求めた $\mathrm{R}$ 值とは $r=0.219$ (n.s.) といずれも有意な相関は得ら れなかった（図 5 )。

\section{考察}

$\mathrm{R}$ 值は元来 single needle dialysis において考慮され ていたが, 通常の透析でも効率の点から Delano ${ }^{9)}$ は R 值 は 0.2 以下が望ましい事を指摘し，最近 Windus ら ${ }^{8)}$ 高流量透析においてシャント機能の評価法として有用性 

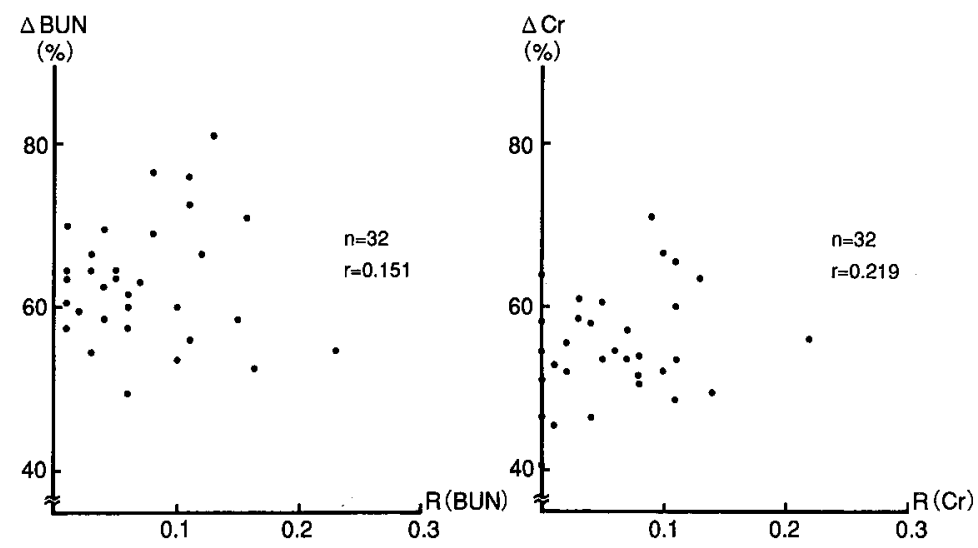

図 5 Reduction rate of $\mathrm{BUN}$ or $\mathrm{Cr}$ concentration vs. fractional recirculation. $\triangle \mathrm{BUN}:(\mathrm{A}-\mathrm{B}) / \mathrm{A} \times 100, \mathrm{~A}: \mathrm{BUN}$ concentration at initiating dialysis, $\mathrm{B}$ : BUN concentration at ending dialysis. $\Delta \mathrm{Cr}$ : calculated as same as $\triangle B U N$.

が高く,透析効率維持には R 值 0.15 以下が必要であると 報告している．今回の結果でも図 $3 ， 4$ に示された如く シャント血流量と R 值は高い負の相関を示し，R值 0.15 以下では平均 $259.4 \mathrm{~m} l / \mathrm{min}$ のシャント血流量が確認さ れており, Delano ${ }^{9)}$, Windus ら ${ }^{8)}$ の見解を支持する結果 であった. 今回は blood pump setting $\left(Q_{b}\right)=200 \mathrm{~m} / /$ $\min$ の標準的血流量設定でのR值の算出であったが, $\mathrm{Q}_{\mathrm{b}}$ の増量に伴い潜在的シャント不全の顕性化は当然予想さ れる.したがって高流量透析による短時間透析への志向 が高まりつつある最近の状勢下では2,10,11)シャント機能 の評価はことさら不可欠となって㧍り，至適透析設定に おいてR值の確認は今後重要性が高まると思われる。な お，図 5 に扔ける溶質の減少率と R 值との相関が理論上 は負の相関となるべきところ，有意ではないにしても正 の相関係数を示したことは静脈穿刺部位が動脈穿刺部位 より中枢側であっても静脈側還流血の動脈側回路への再 混入の影響があるものと解釈される，したがって正確な 透析効率の評価は教科書に記載されている如くやはり シャント肢以外の末梢血採血もしくは一旦返血後の採血 による評価が不可欠である。

\section{結語}

維持透析患者 32 名を対象として再循環指数（R值）を 求め, 溶質減少率执よびパルスドップラー法によるシャ ント血流量と比較し, シャント評価法としての臨床的意 義を検討した.

1. 非シャント肢抒よびシャント肢の血流量は各及 $28.3 \sim 235.0 \mathrm{ml} / \mathrm{min} \quad(67.7 \pm 44.6 \mathrm{ml} / \mathrm{min})$ と 55.0 $\sim 576.0 \mathrm{ml} / \mathrm{min}(303.0 \pm 152.1 \mathrm{ml} / \mathrm{min})$ で，これらょり 算出されたシャント血流量 $\left(\mathrm{Q}_{\mathrm{B}}\right)$ は $15.4 \sim 466.2 \mathrm{~m} l / \mathrm{min}$ $(238.5 \pm 137.8 \mathrm{~m} l / \mathrm{min})$ であった。
2. BUN 值および $\mathrm{Cr}$ 值で算出された $\mathrm{R}$ 值とシャン 卜血流量とは各々 $\mathrm{r}=-0.658 \quad(\mathrm{p}<0.001), \quad \mathrm{r}=-0.548$ $(\mathrm{p}<0.01)$ と有意な負の相関を示した.

3. 溶質 ( $\mathrm{BUN}, \mathrm{Cr}$ ) 減少率と $\mathrm{R}$ 值とは各々 $\mathrm{r}=0.151$ (n. s.)，r=0.219 (n. s.) と有意な相関は得られなかった。 以上より，我々が検討した再循環指数（R值）を求め ることによりシャント不全の定量的推定が可能であり， 本法は種々の診断装置による推定法に比へ，技術的にも 簡単に行元，再現性の面に扔いても問題なく，臨床的有 用性が高いと考えられた。

\section{文献}

1) Gotch FA, Sargent JA : A mechanistic analysis of the National Cooperative Dialysis Study (NCDS). Kidney Int $28: 526-534,1985$

2）中川成之輔：短時間透析之至適透析. 臨牀透析 3 : 293-297, 1992

3）白石幸三，久保和雄：長期透析患者における動静脈 瘦の心機能の影響について。透析会誌 $19: 673-678$, 1986

4) Gothlin J, Lindstedt E, Olin T: A dyedilution method for the determination of blood flow in Cimino-Brescia arteriovenous fistulae. Investigative Urology 15 : 167-168, 1976

5）金津和郎, 永井博之, 池田正尚, 鈴木稚紹, 原 晃： 血液透析用内シャントのシャント量と循環動態に及 ぼす影響について。腎と透析 4：421-426，1978

6) Bibra H, Castro L, A,utenrieth G, McLeid A, Gurland J: The effects of arteriovenous shunts on cardiac function in renal dialysis patients on 
echocardiographic evaluation. Clin Nephrol 9 : 205-209, 1978

7）岡本清也，木倉敏彦，根井仁一，寺中正昭：パルス ドップラー法による血液透析患者ブラッドアクセス の評価. 透析会誌 $23: 199-205,1990$

8) Windus DW, Audrain J, Vanderson R, Jendrisak MD : Optimization of highefficiency hemodialysis by detection and correction of fistula dysfunction.
Kidney Int $38: 337-341,1990$

9) Delano BG: Regular dialysis treatment (RDT), in Replacement of Renal Function by Dialysis, edited by William D, Frank MP and John FM, 1983, p391-409

10）木村玄次郎：短時間透析. 透析会誌 $24: 1-6,1991$

11）鈴木正司：透析時間の短縮化への流れ。臨牀透析 $8: 287-292,1992$ 